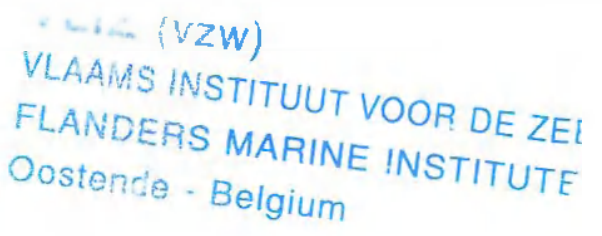

Fish \& Shellfish Tmmunology 23 (2007) 141-153
Fish \& Shellfish

Immunology

www.elsevier com locate/fsi

\title{
Influence of different yeast cell-wall mutants on performance and protection against pathogenic bacteria (Vibrio camphellii) in gnotobiotically-grown Artemia
}

\author{
Siyavash Soltanian ${ }^{\mathrm{a} \cdot \mathrm{b}, *}$, Jean Dhont ${ }^{\mathrm{a}}$, Patrick Sorgeloos ${ }^{\mathrm{a}}$, Peter Bossier ${ }^{\mathrm{a}}$ \\ a Laboratory of Aquaculture \& Artemia Reference Center, Faculty of Bioscience Engineering, Ghent Lniversity. \\ Rozier 44, 9000 Gent, Belgium \\ 'Aquatic Animal Health \& Diseases Department, School of Veterinary Medicine, \\ Shiraz University, Islamic Republic of Iran
}

Received 22 May 2006; revised 18 September 2006; accepted 29 September 2006

Available online 11 October 2006

\begin{abstract}
A selection of isogenic yeast strains (with deletion for genes involved in cell-wall synthesis) was used to evaluate their nutritinnal and immunostimulatory characteristics for gnotobiotically-grown Artemia. In the first set of experiments the nutritional value of isngenic yeast strains (effected in mannoproteins, glucan, chitin and cell-wall bound protein synthesis) for gnotobiotically-grown Artemia was studied. Yeast cell-wall mutants were always better feed for Artemia than the isogenic wild type mainly because they supported a higher survival but not a stronger individual growth. The difference in Artemia performance between WT and mutants feeding was reduced when stationary-phase grown cells were used. These results suggest that any mutation affecting the yeast cellwall make-up is sufficient to improve the digestibility in Artemia. The second set of experiments, investigates the use of a small amount of yeast cells in gnotobiotic Artemia to overcome pathogenicity of Vibrio campbellii (VC). Among all yeast cell strains used in this study, only mnn9 yeast (less cell-wall bound mannoproteins and more glucan and chitin) seems to completely protect Artemia against the pathogen. Incomplete protection against the pathogen was obtained by the gas 1 and chs 3 mutants, which are lacking the gene for a particular cell-wall protein and chitin synthesis, respectively, resulting in more glucan. The result with the chs3 mutant is of particular interest, as its nutritional value for Artemia is comparable to the wild type. Hence, only with the chs3 strain, in contrast to the gas 1 or mnn9 strains, the temporary protection to VC is not concomitant with a better growth performance under non-challenged conditions, suggesting non-interference of general nutritional effects.
\end{abstract}

(C) 2006 Elsevier Ltd. All rights reserved.

Keywords: Arlemia; Gnotobintic culture; Saccharomyces cerevisiae: Isogenic yeast mutants; Immune ability; Vibrio campbellii

\footnotetext{
* Corresponding author. T.ahoratory of Aquaculture \& Artemia Reference Center, Faculty of Bioscience Fngineering. Ghent University, Rozier 44 , 9000 Gent, Belgium. Tel.: +32 92643754; fax: +3292644193.

F-mail address: soltanian.siyavash@ugent.be (S. Soltanian).
} 


\section{Introduction}

Immunomodulation of larval fish has been proposed as a potential method for improving larval survival hy increasing the innate responses of the developing animals until their adaptive immune response is sufficiently developed to increase an effective response to the pathogen [1].

Invertebrates are not equipped with cells that are analogous to antibody producing lymphocytes in vertebrates. According to Raa [2], invertebrates are apparently entirely dependent on non-specific immune mechanisms to cope with infections, as they lack the specific immunological "memory" that is found in fish and warm-blooded animals. As a result, it does not seem to make sense to vaccinate them against any specific diseases.Yet, a recent study in the copepod Macrocyclops albidus showed that the defence system of this invertebrate species reacted more efficiently after a previous encounter with an antigenically similar parasite, implying that a specific memory may exist [3]. Furthermore, exposure of shrimp to inactivated Vibrio spp. has been reported to provide some protection [4-6]. The use of specific biological compounds (immunostimulants) that enhance immune responses of target organisms, rendering animals more resistant to diseases may be an excellent preventive tool against pathogens [7]. Such substances may reduce the risk of disease outbreaks if administered prior to a situation known to result in stress and impaired general performance (e.g. handling stress, change of temperature or other environmental parameters, weaning from live to artificial feeds) or prior to an expected increase in exposure to pathogenic micro-organisms and parasites (e.g. spring and autumn blooms in marine environment, transfer to engrowing systems).

Several immunostimulants have been used in vertehrate and invertebrate culture, to induce protection against a wide range of diseases: i.e. $\beta$-glucans [8-11], chitin [12-14], mannoproteins [15], lipopolysaccharides [16], peptidoglycans $[5,17]$ and dead bacteria $[4,18,19]$.

Marques et al. $\{20,21\}$ have recently developed and validated the usefulness of an Artemia gxotobiotic test system allowing to study the effect of fond composition on survival and growth in the presence or absence of a pathogen. Baker's yeast Saccharomyces cerevisiae, which has been found to be a good immune enhancer in some aquatic organism, is an excellent source of $\beta$-glucans and chitin. These compounds together with mannoproteins constitute the major compounds of the yeast cell wall [22]. The present study aims to identify the critical cell-wall components that induce pathogen-protection in Artemia. The effect of isogenic yeast deletion mutants (eight strains), carrying a null mutation in a gene involved in cell-wall synthesis, was evaluated in a gnotobintic Artemia test system. Firstly, Artemia performance was examined with the null-mutant yeast cells, harvested in exponential and/or stationary growth phase. In a second stage, these feed sources were tested in combination with a Vibrio camphellii challenge.

\section{Methodology}

\subsection{Axenic culture of yeast}

To verify the digestibility of live baker's yeast ( $S$. cerevisiae) by Artemia, seven different null-mutants of yeast (isogenic deletion strains derived from baker's yeast strain BY4741) and the wild type strain (WT) (genotype described in Table 1) were fed to Artemia. All strains were provided by EUROSCARF (University of Frankfurt, Germany).

Yeast cultures were performed according to procedures previously described by Marques et al. [20], using minimal Yeast Nitrogen Base culture medium (YNB).

Yeasts were harvested by centrifugation ( $1800 \times \mathrm{g}$ for $10 \mathrm{~min}$ ), either in the exponential growth phase (after $20 \mathrm{~h}$; "exp.yeast") or in the stationary growth phase (after 3 days; "stat.yeast"). Yeast cell concentrations were determined with a Bürker haemocytometer. Yeast suspensions were stored at $4{ }^{\circ} \mathrm{C}$ until the end of each experiment (maximum storage of one week).

\subsection{Bacterial strains and growth conditions}

Two bacterial strains were selected, i.e. Aeromonas hydrophila strain LVS3 [23-25] for its positive effect on Artemia performance when fed sub-optimally and Vibrio campbellii strain LMG21363 (VC) for its pathogenic effect towards Artemia and shrimp [25-27]. The two bacterial strains were cultured and harvested according to procedures previously described by Marques et al. [25]. Pure cultures of the two bacterial strains were obtained from the Laboratory of Microbial Ecology and Technology, Gent University: and from the Laboratory of Microbiology, 
Table 1

Genotype of all yeast strains used as feed for Attemia and description of each gene mutation in the development of cell-wall components

\begin{tabular}{|c|c|c|c|}
\hline $\begin{array}{l}\text { Strains } \\
\text { nat }\end{array}$ & Genotype & $\begin{array}{l}\text { Phenotype } \\
\text { (cell-wall changes) }\end{array}$ & Reference \\
\hline WT & $\begin{array}{l}\text { BY4741: Mat a; his } 3 \Delta \mathrm{l} \text {; leu } \\
2 \Delta 0 ; \text { met } 15 \Delta 0 ; \text { ura } 3 \Delta 0\end{array}$ & Control yeast & $\begin{array}{l}\text { Dallies et al. [43]; Klis et al. [35]; } \\
\text { Magnelli et al. [22]; Marques et al. }[20,21]\end{array}$ \\
\hline mnn6 & 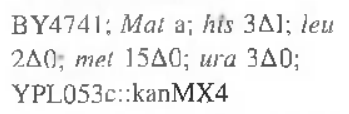 & Less phosphomannan & $\begin{array}{l}\text { Karson and Ballou [44]; Wang and Nakayama [45]; } \\
\text { Jigami and Odani [34] }\end{array}$ \\
\hline $\mathrm{fk}, \mathrm{s}]$ & 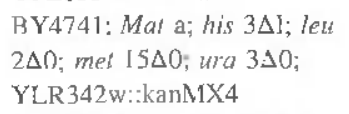 & $\begin{array}{l}\text { Less } \beta-1,3 \text { glucans, } \\
\text { higher chitin }\end{array}$ & $\begin{array}{l}\text { Dallies et al. [43]; Magnelli et al. [22]; } \\
\text { Martin-Yken et a]. [307; Pagé et al. [46]; } \\
\text { Aguilar-Useanga and Francois [29] }\end{array}$ \\
\hline knr4 & 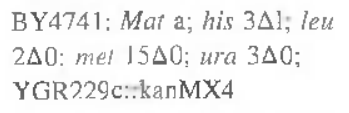 & $\begin{array}{l}\text { Less } \beta-1,3 \text { glucans, } \\
\text { higher chitin }\end{array}$ & $\begin{array}{l}\text { Dallies et al. }\{431 ; \text { Magnelli et al. [22]; } \\
\text { Martin-Yken et al. [30]; Pagé et a]. [46;: } \\
\text { Aguilar-Uscanga and Francois [29] }\end{array}$ \\
\hline $\operatorname{chs} 3$ & $\begin{array}{l}\text { BY4741: Mat a; his } 3 \Delta 1 \text {; leu } \\
2 \Delta 0 ; \text { met } 15 \Delta 0 \text {; ura } 3 \Delta 0 \\
\text { YBR023c:kanMX } 4\end{array}$ & Less chitin & $\begin{array}{l}\text { Va]divieso et al. [47]; Cabib et ai. [31]; } \\
\text { Klis et al. [35]; Magnelli et al. [22]; }\end{array}$ \\
\hline gas1 & 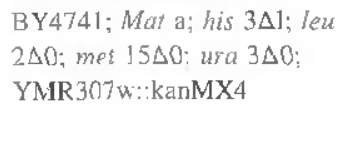 & $\begin{array}{l}\text { Less integration of yeast } \\
\text { cell auhesion proteins } \\
\text { into the cell wall less } \\
\beta-1,3 \text { glucans, higher chitin }\end{array}$ & $\begin{array}{l}\text { De Nobel et al. [38]; Popolo et al. [48]; } \\
\text { Lipke and Ovalle [33]; Magnelli et al. [221 }\end{array}$ \\
\hline
\end{tabular}

Gent University. The bacterial strains were stored at $-80^{\circ} \mathrm{C}$ and grown overnight at $28^{\circ} \mathrm{C}$ on marine agar, containing Difco $^{\mathrm{TM}}$ marine broth 2216 (37.4 $\mathrm{g}^{-1}$, BD Biosciences) and agar bacteriological grade $\left(20 \mathrm{~g} \mathrm{l}^{-1}, \mathrm{ICN}\right)$. For each bacterial strain a single colony was selected from the plate and incubated overnight at $28^{\circ} \mathrm{C}$ in $50 \mathrm{ml}$ Difco ${ }^{\mathrm{TM}}$ marine broth 2216 on a shaker $(150 \mathrm{rpm})$. Stationary-grown bacteria were harvested by centrifugation $(15 \mathrm{~min} ; \pm 2200 \times \mathrm{g})$; the supermatant were discarded and the pellet resuspended in $20 \mathrm{ml}$ filtered autoclaved sea water (FASW). Bacterial densities were determined by spectrophotometry $\left(\mathrm{OD}_{550}\right)$, assuming that an optical density of 1.000 corresponds to $1.2 \times 10^{9} \mathrm{cells} \mathrm{ml}^{-1}$, according to McFarland standard (Biomerieux, Marcy l'Etoile, France).

Bacteria were resuspended in filtered autoclaved sea water (FASW) and their densities were determined by spectrophotometry $\left(\mathrm{OD}_{550}\right)$, assuming that an optical density of 1.000 corresponds to $1.2 \times 10^{9}$ cells $\mathrm{ml}^{-1}$, according to McFarland standard (Biomerieux, Marcy l'Etoile, France).

At day 3, challenge tests were performed with live VC. For that purpose, in a laminar flow hood, the pathogen was

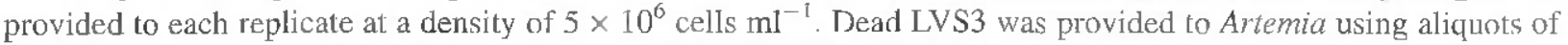
autoclaved concentrated bacteria (autoclaving at $120^{\circ} \mathrm{C}$ for $20 \mathrm{~min}$ ). After autoclaving, bacteria were plated to check if they were effectively killed by this method. For this purpose, $100 \mu \mathrm{l}$ of the culture medium were transferred to marine agar (MA; $n=3$ ), containing Difco ${ }^{\mathrm{TM}}$ marine broth 2216 (BD Biosciences, 3.74\% w/v) and agar bacteriological grade (ICN, 2\% w/v). Absence of bacterial growth was monitored after incubating plates for 5 days at $28^{\circ} \mathrm{C}$. Autoclaving treatment was $100 \%$ effective, since no bacterial growth was observed on the MA after 5 days of incubation. Dead and live bacterial suspensions were stored at $4^{\circ} \mathrm{C}$ until the end of each experiment.

\subsection{Yeast and bacterial ash-fiee content}

To determine the yeast and bacterial ash-free dry weight (AFDW), $50 \mathrm{ml}$ of each culture sample were filtered on pre-dried filters (pore size $0.45 \mu \mathrm{m}$, two replicate per culture). Filters were subsequently dried at $60{ }^{\circ} \mathrm{C}$ for $24 \mathrm{~h}$ and weighed. Afterwards they were combusted at $600^{\circ} \mathrm{C}$ for $6 \mathrm{~h}$ to determine the ash content. The AFDW was calculated as the difference between dry weight and ash weight. The DW and AFDW of control (filter only, $n=2$ ) were subtracted from all samples. The AFDW of the yeast strains and the hacteria is presented in Table 2. 
Table 2

Average ash-free dry weight (AFDW) of seven different null-mutants of yeast (isogenic strains derived from BY 4741) and the wild type strain (WT) harvested in the exponential and stationary growth phase, logether with AFDW of dead LVS3 and live VC hacteria expressed in mg/10 ${ }^{9}$ cells

\begin{tabular}{|c|c|c|c|c|c|}
\hline \multirow[t]{2}{*}{ Strains } & \multicolumn{2}{|c|}{ AFDW (mg/10 cells) } & \multicolumn{2}{|c|}{ AFDW (mg/Falcon tube) } & \multirow{2}{*}{$\begin{array}{l}p \text {-value } \\
\text { Exponential } \\
\text { vs stationary } \\
\text { phase AFDW } \\
\text { (mg/Falcon tube) }\end{array}$} \\
\hline & $\begin{array}{l}\text { Exponential } \\
\text { phase }\end{array}$ & $\begin{array}{l}\text { Stationary } \\
\text { phase }\end{array}$ & $\begin{array}{l}\text { Exponential } \\
\text { phase }\end{array}$ & $\begin{array}{l}\text { Stationary } \\
\text { phase }\end{array}$ & \\
\hline WT & $15.24 \pm 0.18^{r}$ & $13.69 \pm 0.07^{d}$ & $1.60 \pm 0.02^{\mathrm{e}}$ & $1.44 \pm 0.0 \mathrm{r}^{\mathrm{de}}$ & 0.014 \\
\hline mnn9 & $54.67 \pm 1.66^{\mathrm{a}}$ & $36.40 \pm 7.23^{a}$ & $5.74 \pm 0.17^{\mathrm{a}}$ & $3.82 \pm 0.75^{a}$ & 0.161 \\
\hline mnn6 & $17.09 \pm 0.37^{\mathrm{e}}$ & $11.83 \pm 0.10^{\mathrm{de}}$ & $1.79 \pm 0.04^{\mathrm{d}}$ & $1.24 \pm 0.0 \mathrm{I}^{\mathrm{e}}$ & 0.013 \\
\hline $\mathrm{fks} l$ & $18.90 \pm 1.41^{d}$ & $17.73 \pm 0.28^{\mathrm{c}}$ & $1.98 \pm 0.13^{d}$ & $1.86 \pm 0.0^{\mathrm{cd}}$ & 0.644 \\
\hline knr4 & $14.77 \pm 0.26^{f}$ & $13.17 \pm 0.13^{\mathrm{d}}$ & $1.55 \pm 0.03^{\mathrm{e}}$ & $1.38 \pm 0.10^{\text {de }}$ & 0.037 \\
\hline kre6 & $34.54 \pm 1.41^{b}$ & $24.52 \pm 1.25^{\mathrm{b}}$ & $3.63 \pm 0.28^{\mathrm{b}}$ & $2.57+0.13^{\mathrm{h}}$ & 0.076 \\
\hline $\operatorname{chs} 3$ & $16.4 \pm 0.12^{e}$ & $11.0 \pm 0.40^{\mathrm{e}}$ & $1.72 \pm 0.01^{\mathrm{d}}$ & $1.15 \pm 0.04^{e}$ & 0.020 \\
\hline gas 1 & $29.09 \pm 0.86^{\circ}$ & $20.30 \pm 2.60^{h c}$ & $13.05 \pm 0.09^{c}$ & $2.13 \pm 0.28^{h c}$ & 0.1 \\
\hline Live LVS3 & - & $0.2186 \pm 0.02^{\mathrm{f}}$ & - & $0.023 \pm 0.01^{\mathrm{f}}$ & - \\
\hline Dead LVS3 & $m$ & $0.2725 \pm 0.02^{f}$ & - & $0.029 \pm 0.0 l^{\prime}$ & - \\
\hline Live VC & - & $0.1134 \pm 0.01^{1}$ & - & $0.034 \pm 0.01^{f}$ & - \\
\hline
\end{tabular}

Values of AFDW are presented with the respective standard deviation (mean \pm SD). Values in the same column showing the same superscript letter are not significantly different $\left(p_{\text {Tuk }{ }^{\prime} y}>0.05\right.$ ). p-values obtained for direct comparison of AFDW (mg/Falcon tube) of different yeast cell strains, harvested in exponential and stationary growth phase were included. Significant differences were obtained when $p$ Tukey $<0.05$.

\subsection{Artemia gnotobiotic culture}

Experiments were performed with Artemia franciscana cysts, originating from Great Salt Lake, Utah, USA (EG ${ }^{\text {(i) }}$ type, INVE Aquaculture, Belgium). Bacteria-free cysts and nauplii were obtained using the procedure described by Marques et al. [20]. After hatching, 20 nauplii (Instar II) were picked and transferred to Falcon tubes containing $30 \mathrm{ml}$ of FASW together with the amount of feed scheduled for day 1. Feeding rates were intended to provide ad libitum ratios but avoiding excessive feeding in order not to affect the water quality in the test tuhes, except in Experiments 4 and 5 (treatments 19 and 20) where nauplii were overfed (5.74 mg AFDW/FT) (Table 5, feeding regime: (d) in order to verify the effect of overfeeding. Fach treatment consisted of four Falcon tubes (replicates). Falcon tubes were placed on a rotating rod at 4 cycles per min, exposed to constant incandescent light $\left(t 41 \mu \mathrm{Em}^{-2}\right)$ at $28{ }^{\circ} \mathrm{C}$. Tubes were being transferred to the laminar flow just once per day for feeding.

\subsection{Method used to verify axenity}

Axenity of feed, decapsulated cysts and Artemia cultures were checked at the end of each experiment using a combination of plating (MA) and live counting (using tetrazolium salt MTT staining following the procedure described by Marques et al. $[20,21]$. In challenge treatments, the axenity of Artemia culture was always checked hefore challenge using the same methods. Contaminated culture tubes were not considered for further analysis and the treatment was repeated.

\subsection{Experimental design}

In Experiment 1, all live and axenic yeast strains (WT and seven null mutants) were harvested in the exponential growth phase and used as feed for the Artemia.

In Experiment 2, stationary-grown live and axenic yeast strains (the same strains as used in Exp. 1) were used as feed for nauplii. In both experiments, a modified feeding schedule was adopted from Coutteau et al. [28] and Marques et al. [20]. The feeding schedule resulted in an equal amount of yeast-cell particles per treatment being offered to Artemia. Both experiments were performed twice (A and B), to verify the reproducibility of the results.

In Experiment 3, an equal amount of feed was provided to Artemia (Table 5). As the AFDW per cell of the yeast mutants is different (see Table 2), this resulted in different amount of yeast cells being offered. Each feed was tested in four replicates. 
In Experiments 4 and 5, all treatments were fed with an equal amount of yeast (in terms of AFDW). Yeast strains (in exponential and/or stationary grow $1 \mathrm{~h}$ phase) were provided daily in small but equal amounts, in combination with dead LVS3 (as a major part of the feed) to Artemia (Table 5 - feeding regime for Exps. 4 and 5). As a control, Artemia was fed only dead LVS3 (Table 5 - feeding regime: (c). Challenge tests were performed with live VC at a density of $5 \times 10^{6}$ cells $\mathrm{ml}^{-1}$ added at day 3 .

\subsection{Survival and growth of Artemia}

Survival and growth of Artemia nauplii were determined according to procedures described by Marques et al. $[20,21]$. At the end of Experiments 1, 2 and 3 (day 6 after hatching) the number of swimming larvae was determined and survival percentage was calculated. Living larvae were fixed with Lugol's solution to measure their individual length (growth calculation), using a dissecting microscope equipped with a drawing mirror, a digital plan measure and the software Artemia 1.0 (Marnix Van Domme). In order to integrate the results of survival and growth, the criterion "total length" was introduced, i.e. total millimeters of Artemia per Falcon tube or mm/FT = number of survivors $\times$ mean individual length.

In Experiments 4 and 5 the survival percentage for each treatment was determined daily. For this purpose, the numher of live Artemia was registered before feeding (or adding any bacteria) by exposing each transparent Falcon tube to an incandescent light without opening the tube to preserve the axenity.

Values of larval survival (percentage) were arcsin transformed, while values of individual length and total length were logarithmic or square root transformed to satisfy normal distribution and homocedasticity requirements. Differences on survival, individual length and total length of Artemia fed with different feeds, were studied with analysis of variances (ANOVA) and multiple comparisons of Tukey's range, tested at 0.05 level of probability, using the software Spss 11.5 for Windows.

\section{Results}

\subsection{Artemia performance fed live yeast cells}

Artemia nauplii were fed with seven different isogenic mutant strains of baker's yeast (Saccharomyces cerevisiae) (Table 1) and compared with nauplii fed wild type yeast under gnotobiotic condition. In all cases equal amounts of yeast cells were offered. The results presented in Tables 3 and 4 (results obtained in Exps. 1 and 2) show that independently of the growth stage, the yeast genetic background has a big influence on Artemia performance. Compared with WT yeast, total biomass production of nauplii was significantly improved when the exp-grown isogenic yeast mutant strains were used as feed, due to both significant higher survival and/or individual length (Table 3). Among them, the mnn9 yeast strain supported the best nauplii performance.

Table 3

Experiment 1: average survival (c), individual length (mm) and total length ( $\mathrm{mm}$ per Falcon tube-FT) of Artemia nauplii fed with live yeast cells (harvested in exponential growth phase) after 5 days: effect of growth stage and genetic hackground

\begin{tabular}{|c|c|c|c|c|c|c|}
\hline \multirow[t]{2}{*}{ Strains } & \multicolumn{3}{|l|}{$\mathrm{A}$} & \multicolumn{3}{|l|}{$\mathrm{B}$} \\
\hline & Survival $(\%)$ & $\begin{array}{l}\text { Individual } \\
\text { length (mm) }\end{array}$ & $\begin{array}{l}\text { Total length } \\
(\mathrm{mm} / \mathrm{FT})\end{array}$ & Survival $(\%)$ & $\begin{array}{l}\text { Individual } \\
\text { length }(\mathrm{mm})\end{array}$ & $\begin{array}{l}\text { Total length } \\
(\mathrm{mm} / \mathrm{TT})\end{array}$ \\
\hline $\operatorname{mnn} 9$ & $87 \pm 9^{a}$ & $4.0 \pm 0.4^{\mathrm{a}}$ & $70.7 \pm 7.7^{\mathrm{a}}$ & $87 \pm 6^{4}$ & $3.9 \pm 0.2^{\mathrm{a}}$ & $68.7 \pm 5.0^{\mathrm{a}}$ \\
\hline $\operatorname{mnn} 6$ & $64+7^{\mathrm{bc}}$ & $1.8 \pm 0.1^{\mathrm{de}}$ & $23.5 \pm 2.6^{c}$ & $52 \pm 6^{\mathrm{bc}}$ & $1.8 \pm 0.2^{\mathrm{d}}$ & $19.0 \pm 2.3^{\mathrm{cd}}$ \\
\hline $\mathrm{fks}]$ & $55 \pm 10^{\mathrm{b}}$ & $2.1 \pm 0.1^{c}$ & $23.6 \pm 4.6^{c}$ & $50+12^{b c}$ & $2.2 \pm 0.3^{\mathrm{cd}}$ & $20.0 \pm 9.0^{\mathrm{cd}}$ \\
\hline kre6 & $45 \pm 4^{\mathrm{bc}}$ & $2.0 \pm 0.1^{\mathrm{cd}}$ & $18 \pm 1.6^{\mathrm{c}}$ & $58 \pm 13^{b}$ & $2.5 \pm 0.1^{c}$ & $29.0 \pm 6.0^{c}$ \\
\hline $\operatorname{chs} 3$ & $55 \pm 5^{\mathrm{b}}$ & $1.7 \pm 0.2^{\mathrm{e}}$ & $18.5 \pm 2.0^{c}$ & $42+5^{b c}$ & $2.0 \pm 0.2^{\mathrm{cd}}$ & $17.0 \pm 2.0^{\mathrm{cd}}$ \\
\hline
\end{tabular}

Means were put together with the standard deviation (mean \pm SD). Each experiment was repeated twice A and B. Each feed was tested in four replicates. Values in the same column showing the same superscript letters are not significantly different $\left(p_{\text {Tukey }}>0.05\right)$. 
Table 4

Experiment 2: average survival ( $\%$ ), jndividual length (mm) and total length (mm per Falcon tube-FT) of Artemia nauplii fed with live yeast cells (harvested in the stationary growth phase) after 5 days: effect of growth stage and genetic background

\begin{tabular}{|c|c|c|c|c|c|c|}
\hline \multirow[t]{2}{*}{ Strains } & \multicolumn{3}{|l|}{ A } & \multicolumn{3}{|l|}{ B } \\
\hline & Survival $(\%)$ & $\begin{array}{l}\text { Individual } \\
\text { length (mm) }\end{array}$ & $\begin{array}{l}\text { Total length } \\
(\mathrm{mm} / \mathrm{FT})\end{array}$ & Survival $(\tilde{T})$ & $\begin{array}{l}\text { Individual } \\
\text { length (mm) }\end{array}$ & $\begin{array}{l}\text { Total length } \\
(\mathrm{mm} / \mathrm{HT})\end{array}$ \\
\hline$\overline{\text { WT }}$ & $15 \pm 7^{d}$ & $1.75 \pm 0.2^{\text {bcd }}$ & $5.2 \pm 2.5^{c}$ & $25 \pm 4^{c}$ & $1.7 \pm 0.2^{\mathrm{bc}}$ & $8.5 \pm 1.4^{\mathrm{c}}$ \\
\hline mnng & $68 \pm 5^{a}$ & $3.3 \pm 0.2^{\mathrm{a}}$ & $45.6 \pm 3.2^{\mathrm{a}}$ & $71 \pm 4^{a}$ & $2.8 \pm 0.1^{a}$ & $40.0 \pm 27^{a}$ \\
\hline mnnt & $40 \pm 4^{b c}$ & $1.8 \pm 0.1^{b c}$ & $14.4 \pm 1.5^{b}$ & $38 \pm 8^{h c}$ & $1.3 \pm 0.1^{d}$ & $9.8+1.9^{h c}$ \\
\hline $\mathrm{fks} 1$ & $18 \pm 3^{d}$ & $1.7 \pm 0.2^{\text {hed }}$ & $6.6 \pm 0.9^{c}$ & $28 \pm 13^{b c}$ & $1.6 \pm 0.2^{\mathrm{bc}}$ & $9.4 \pm 1.9^{\mathrm{bc}}$ \\
\hline gas 1 & $35 \pm 4^{b c}$ & $2.0 \pm 0.3^{\mathrm{b}}$ & $14.3 \pm 1.7^{\mathrm{b}}$ & $40 \pm 7^{b}$ & $1.8 \pm 0.1^{\mathrm{h}}$ & $14.9 \pm 2.6^{b}$ \\
\hline knr4 & $48 \pm 5^{\mathrm{b}}$ & $1.3 \pm 0.2^{d}$ & $13.2 \pm 1.3^{b}$ & $35 \pm 4^{b c}$ & $1.5 \pm 0.1^{\mathrm{cd}}$ & $10.4 \pm 1.2^{b c}$ \\
\hline kre6 & $40 \pm 13^{\mathrm{bc}}$ & $1.6 \pm 0.1^{\mathrm{cd}}$ & $12.6 \pm 4.0^{h}$ & $32 \pm 15^{b}$ & $1.6 \pm 0.2^{\text {bcd }}$ & $12.2 \pm 2^{\mathrm{bc}}$ \\
\hline chs 3 & $29 \pm 8^{\mathrm{cd}}$ & $1.7 \pm 0.2^{b c d}$ & $9.7 \pm 2.9^{h c}$ & $25 \pm 6^{\mathrm{bc}}$ & $1.9 \pm 0.1^{\mathrm{b}}$ & $9.3 \pm 2.2^{\text {he }}$ \\
\hline
\end{tabular}

Means were put together with the standard deviation (mean \pm SD). Each experiment was repeated twice A and $\mathrm{B}$. Fach feed was tested in four replicates. Values in the same column showing the same superscript Jetters are not significantly different $\left(p_{\text {Tukey }}>0.05\right)$.

Also the use of the mmn6 mutant resulted in a significantly improved total biomass production of Artemia. In this treatment a higher biomass production was obtained due to a considerable increase in survival. Using knr4 and fks 1 (less $\beta-1,3$ glucans) and kre6 (less $\beta-1,6$ glucans) as feed resulted in less Artemia biomass production compared to the mnn9 yeast strain but significantly more Artemia biomass production compared to the WT yeast. The chitin-defective yeast strain (chs3) supported a small increase in Artemia biomass production compared to the WT-treatment, mainly due to better nauplii survival. Finally, using the gas 1 mutant as food (this strain is lacking an important cell-wall protein involved in cross-linking the major cell-wall components) resulted in better nauplii performance compared to WT yeast.

Higher total biomass (except for fks1 fed Artemia) production (compared to WT) in Artemia fed mutant stat-grown yeast cells were mainly due to higher nauplii survival rather than stronger individual growth. Only with stat-grown mnn 9 cells higher survival and stronger individual growth contributed to more biomass production. When exp-yeast cells were fed to the nauplii, significant higher total Artemia biomass production (mostly due to higher nauplii survival) values were observed in all cases compared with stat-yeast cells possibly because the AFDW of yeast cells in the exponential growth phase was higher than in the stationary growth phase (Table 2) (although not significantly different in the mnn9, gas1 and fks1 yeast strains).

In the experiments described above equal amounts of yeast cell particles (Table 5 - feeding regime for Exp. 3) were supplied as food, resulting, however, in different amounts of AFDW of food offered to Artemia (see Tahle 2). This could have been the reason for the considerable higher Artemia biomass production e.g. with mnn9 yeast. Hence, the feeding experiment was repeated, this time offering equal amounts of food expressed as AFDW. In all cases. feeding mutant-yeast cells resulted in better nauplii survival than feeding WT yeast. Also in this experiment, 1he mnn9-fed Artemia presented the highest biomass production (Table 6). Artemia biomass production was equal after feeding WT,

Table 5

Feeding regimes in the 3 experiments (Fxp.) performed. Daily and average total ash-free dry weight (AFDW), expressed in $\mu \mathrm{g} / \mathrm{FT}$ of yeast cells and dead hacteria (LVS3) supplied to Artemia in Experiments 3, 4 and 5

\begin{tabular}{|c|c|c|c|c|c|c|c|c|c|c|c|}
\hline & \multicolumn{10}{|c|}{ Feeding regime } & \multirow{3}{*}{$\begin{array}{l}\text { Total AFDW } \\
(\mu \mathrm{g} / \mathrm{FT}) \text { offered }\end{array}$} \\
\hline & \multicolumn{2}{|c|}{ Day $]$} & \multicolumn{2}{|c|}{ Day2 } & \multicolumn{2}{|c|}{ Day3 } & \multicolumn{2}{|c|}{ Day4 } & \multicolumn{2}{|c|}{ Day5 } & \\
\hline & $\mathrm{Y}$ & $\mathrm{DB}$ & $\mathrm{Y}$ & $\mathrm{DB}$ & $\mathrm{Y}$ & $\overline{\mathrm{DB}}$ & $\mathrm{Y}$ & DB & $\bar{Y}$ & DB & \\
\hline Exp. 3 & 124 & 0 & 248 & 0 & 248 & 0 & 324 & 0 & 496 & 0 & 1440 \\
\hline \multicolumn{12}{|c|}{ Exps. 4 and 5} \\
\hline (a) & 25 & 221 & 50 & 442 & 50 & 442 & 62 & 592 & 100 & 886 & 2870 \\
\hline (h) & 50 & 197 & 100 & 394 & 100 & 394 & 124 & 525 & 200 & 786 & 2870 \\
\hline (c) & 0 & 246 & 0 & 492 & 0 & 492 & 0 & 656 & 0 & 984 & 2870 \\
\hline (d) & 0 & 492 & 0 & 984 & 0 & 984 & 0 & 1312 & 0 & 1968 & 5740 \\
\hline
\end{tabular}

Challenge tests were performed with live Vibrio campbellii (VC) at a density of $5 \times 10^{6}$ cells ml $\mathrm{s}^{-1}$ added at day 3 in Experiments 4 and 5 .

(a) Dead LVS3 + yeast 5\%; (b) Dead I.VS3 + yeast 10\%; (c) The treatment dead LVS3 X; and (d) The treatment: dead LVS3 2X.

$\mathrm{X}=$ the $1 \mathrm{ntal}$ amount of feed offered $(2870 \mathrm{\mu g}$ AFDW/FT); $\mathrm{Y}=$ yeast (wild lype and isogenic yeast mutants added at $5 \%$ or $10 \%) ; \mathrm{DB}=\mathrm{dead}$ bacterium L.VS3. 
Table 6

Experiment 3: average survival $(\xi)$, individual length (mm) and total length (mm/FT) of Artemia nauplii fed with live yeast cells (harvested in the stationary grow th phase) for 5 days: effect of genefic hackground

\begin{tabular}{|c|c|c|c|}
\hline Strains & Survival (\%) & $\begin{array}{l}\text { Individual } \\
\text { length (mm) }\end{array}$ & $\begin{array}{l}\text { Total length } \\
(\mathrm{mm} / \mathrm{FT})\end{array}$ \\
\hline$\overline{\text { WT }}$ & $18 \pm 6^{c}$ & $1.74 \pm 0.1^{\circ}$ & $6.1 \pm 2.2^{\mathrm{d}}$ \\
\hline mong & $63 \pm 6^{a}$ & $2.44 \pm 0.1^{\mathrm{a}}$ & $30.6 \pm 3.2^{\mathrm{a}}$ \\
\hline mnn6 & $35 \pm 9^{b}$ & $1.8 \pm 0.1^{\circ}$ & $12.6 \pm 3.3^{\mathrm{bc}}$ \\
\hline $\mathrm{fks} 1$ & $28 \pm 7^{\mathrm{bc}}$ & $1.67 \pm 0.1^{c}$ & $9.2 \pm 2.2^{\mathrm{cd}}$ \\
\hline gas 1 & $38 \pm 6^{\mathrm{b}}$ & $2.11 \pm 0.1^{\mathrm{h}}$ & $15.8 \pm 2.7^{\mathrm{b}}$ \\
\hline $\operatorname{cbs} 3$ & $33 \pm 6^{b}$ & $1.81 \pm 0.1^{\mathrm{c}}$ & $11.8 \pm 2.3^{\mathrm{bcd}}$ \\
\hline
\end{tabular}

Al1 treatments were fed with an equal amount of feed corresponding to an AFDW ( $1.44 \pm 0.01 \mathrm{mg} / \mathrm{FT}$ ) (see Table 5 - Exp. 3) (for instance fed with WT-YNB yeast cells). Means were put together with the standard deviation (mean \pm SD). Each feed was tested in four replicates. Values in the same column showing the same superscript letters are not significantly different $\left(p_{\text {Tykey }}>0.05\right)$.

fks 1 , kre 6 and chs 3 cells although the mutants (kre6 and knr4) display, respectively, a higher or equal AFDW as compared with WT yeast.

\subsection{Protection effect by bacteria (LVS3) and yeast}

The effect of feeding two different amounts of dead bacteria (autoclaved I.VS3) to the nauplii (either challenged or not with a live pathogen) is presented in Table 7 (Exp. 4). Unchallenged, there is no effect on survivat in the two feeding regime. Yet, nauplii fed with dead LVS3 (5.74 mg AFDW/FT) (Table 5, feeding regime: (d) yielded a significantly higher survival in the challenge test as compared to the nauplii fed with only half of this amount (Table 7, lines 20 and 22). The results of supplying a low amount of WT or isogenic yeast mutants to the nauplii fed dead LVS 3 are presented in Tables 7 and 8. Most of the non-challenged nauplii fed solely with dead LVS3 or both dead LVS3 and yeast cells survived until day 6 (68\% or higher). In most trealments, challenged nauplii fed only with dead LVS3 or both dead LVS.3 and yeast cells (WT, mnn6, fks1, knr4, kre6) died before day 5. Yel, exceptions occurred when the nauplii w'ere fed both dead LVS3 and mnn9, gas I and chs3 (only exp-yeast) yeast strains. Only mmn9 yeast cells can protect nauplii against the live pathogen until day 6 (Tables 7 and 8 , line 4). However, the addition of $5 \%$ of the total AFDW in the form of mnn9 yeast cells was not sufficient to keep the nauplii alive until day 6 (Tables 7 and 8 , line 6 ). In all yeast strains, the exp-yeasts provided a better protection against the pathogen than stat-yeasts, but in most cases, this protection lasted only for a short period (one day after challenge). The mnn9 cells supported a high prorection until the end of the experiments against the VC pathogen when offered as exp-grown or stat-grown cells (Tables 7 and 8, line 4).

\section{Discussion}

Marques et al. $[20,21]$ have shown that yeast digestion by Artemia can be significantly improved by manipulating the genetic characteristics of the yeast, the growth stage and the medium used. This study confirms that the genetic background of the yeast strain used, has a strong influence on the Artemia performance (Exps. 1, 2 and 3).

In this study, a yeast strain containing low concentrations of mannoproteins in the cell wall, such as the mnn9 mutant, always supported a high Artemia biomass production (i.e. best nauplii growth as well as highest survival rate). According to Coutteau et al. [28], $\beta$-glucanase activity is detected in the digestive tract of Artemia but no mannase activity, making the external mannoprotein layer of the yeast cell wall probably the major barrier for the digestion of the yeast cell by the Artemia nauplii. Therefore, it is likely that the digestive enzymes of Artemia (such as $\beta$-glucanase) can easily enter and provide suitable digestion of yeast cells with reduced mannoprotein content.

An improved Arteniia performance was also obtained with yeast mutants with reduced $\beta$-glucans (fks1, knr 4 , kre6 and gas1) and chitin (chs3) levels as compared to the nauplii fed WT-yeast cells (especially with exp-grown yeast cells as food). According to Aguilar-Uscanga and Francois [29], $\beta-1,3$ glucans and especially $\beta-1,6$ glucans provide anchorage to most cell-wall mannoproteins and are also covalently linked with chitin, contributing to the modular structure of the cell wall. $\beta-1,3$ glucans also contribute to the rigidity and integrity of the cell wall, and determine the cell 
Table 7

Experimenr 4: mean dafly surviva! (\%) of Artemia fed daily with dead LVS3 and yeast cell strains harvested in the exponential growth phase

\begin{tabular}{|c|c|c|c|c|c|c|c|c|c|c|c|}
\hline \multirow[t]{2}{*}{$\mathrm{TN}$} & & \multicolumn{5}{|c|}{ A - survival (\%) } & \multicolumn{5}{|c|}{$\mathrm{B}-$ survival $(\%)$} \\
\hline & & Day 2 & Day 3 & Day 4 & Day 5 & Day 6 & Day 2 & Day 3 & Day 4 & Day 5 & Day 6 \\
\hline 1 & Dead IVS $3+$ WT $10 \%$ & $93 \pm 3^{a}$ & $86 \pm 3^{a}$ & $81 \pm 5^{a}$ & $74 \pm 4^{a}$ & $68 \pm 3^{a}$ & $91 \pm 3^{\mathrm{a}}$ & $88 \pm 3^{a}$ & $83 \pm 3^{a}$ & $73 \pm 3^{a}$ & $66 \pm 3^{a}$ \\
\hline 3 & Dead LVS $3+\operatorname{mnn} 910 \%$ & $98 \pm 3^{2}$ & $94 \pm 3^{a}$ & $90 \pm 4^{3}$ & $86 \pm 3^{3}$ & $83 \pm 3^{a}$ & $96 \pm 3^{a}$ & $93 \pm 3^{a}$ & $91 \pm 3^{3}$ & $84 \pm 3^{a}$ & $80 \pm 4$ \\
\hline 4 & $\begin{array}{l}\text { Dearl I.VS3 + mnn9 10\% } \\
+ \text { VC D3 }\end{array}$ & $96 \pm 3^{a}$ & $93 \pm 3^{a}$ & $86 \pm 3^{a}$ & $80 \pm 4^{a}$ & $76 \pm 3^{a}$ & $98 \pm 3^{a}$ & $93 \pm 3^{a}$ & $88 \pm 3^{\mathrm{a}}$ & $81 \pm 5^{a}$ & $76 \pm 3^{\mathrm{a}}$ \\
\hline 6 & $\begin{array}{l}\text { Dead IVS3 }+ \text { mnng } 5 \%+ \\
\text { VC. D3 }\end{array}$ & $99 \pm 3^{a}$ & $89 \pm 3^{a}$ & $74 \pm 3^{a}$ & $31 \pm 5^{b}$ & $0^{\mathrm{b}}$ & $98 \pm 3^{2}$ & $91 \pm 3^{a}$ & $81 \pm 3^{a}$ & $35 \pm 4^{b}$ & $0^{h}$ \\
\hline 7 & Dead LVS $3+$ mnn6 $10 \%$ & $93 \pm 3^{a}$ & $89 \pm 3^{a}$ & $83 \pm 5^{\mathrm{a}}$ & $79 \pm 3^{\mathrm{a}}$ & $73 \pm 3^{\mathrm{a}}$ & $91+3^{a}$ & $89 \pm 3^{a}$ & $81 \pm 3^{a}$ & $78 \pm 3$ & $70 \pm 4^{7}$ \\
\hline 8 & $\begin{array}{l}\text { Dead LVS3 + mnn6 10\% } \\
+ \text { VC D3 }\end{array}$ & $91 \pm 3^{a}$ & $88 \pm 3^{n}$ & $66 \pm 5^{h}$ & $0^{\mathrm{b}}$ & $0^{\mathrm{b}}$ & $96 \pm 3^{4}$ & $86 \pm 3^{a}$ & $70 \pm 4^{b}$ & $0^{b}$ & $0^{4}$ \\
\hline 12 & $\begin{array}{l}\text { Dead I.VS3 + knr4 } 10 \% \\
+ \text { VC D3 }\end{array}$ & $93 \pm 3^{a}$ & $86 \pm 3^{a}$ & $63 \pm 3^{b}$ & $0^{\mathrm{b}}$ & $0^{\mathrm{b}}$ & $93 \pm 3^{a}$ & $88 \pm 3^{2}$ & $66 \pm 3^{b}$ & $0^{b}$ & $0^{\mathrm{b}}$ \\
\hline 13 & Dead LVS3 + kre6 $10 \%$ & $94 \pm 3^{4}$ & $88 \pm 3^{a}$ & $80 \pm 4^{a}$ & $75 \pm 4^{a}$ & $71 \pm 3^{\mathrm{a}}$ & $93 \pm 3^{a}$ & $88 \pm 3^{a}$ & $83 \pm 3^{\circ}$ & $78 \pm 3^{a}$ & $70 \pm 4^{9}$ \\
\hline 14 & $\begin{array}{l}\text { Dead LVS3 + kre6 } 10 \% \\
+ \text { VC D3 }\end{array}$ & $94 \pm 3^{a}$ & $88 \pm 3^{a}$ & $60 \pm 4^{b}$ & $0^{\mathrm{b}}$ & $0^{\mathrm{b}}$ & $93 \pm 3^{a}$ & $86 \pm 3^{a}$ & $65 \pm 4^{b}$ & $0^{\mathrm{b}}$ & $0^{\mathrm{h}}$ \\
\hline 15 & Dear I.VS3 + gas $110 \%$ & $93 \pm 3^{a}$ & $88 \pm 3^{a}$ & $84 \pm 3^{a}$ & $81 \pm 3^{a}$ & $73 \pm 3^{a}$ & $94 \pm 3^{3}$ & $89 \pm 3^{a}$ & $86 \pm 3^{a}$ & $78 \pm 3^{a}$ & $71 \pm 5^{a}$ \\
\hline 16 & $\begin{array}{l}\text { Dead LVS. + gas1 10\% } \\
+ \text { VC D3 }\end{array}$ & $94 \pm 3^{a}$ & $86 \pm 3^{a}$ & $50 \pm 4^{b}$ & $36 \pm 4^{b}$ & $0^{\mathrm{h}}$ & $93 \pm 3^{a}$ & $88 \pm 3^{a}$ & $53 \pm 6^{b}$ & $33 \pm 6^{h}$ & $0^{h}$ \\
\hline 17 & Dead LVS $3+\operatorname{chs} 310 \%$ & $94 \pm 3^{2}$ & $86 \pm 3^{a}$ & $79 \pm 5^{3}$ & $79 \pm 5^{a}$ & $75 \pm 3^{a}$ & $96 \pm 3^{a}$ & $88 \pm 3^{a}$ & $81 \pm 5^{a}$ & $75 \pm 4^{a}$ & $74 \pm 3^{7}$ \\
\hline 18 & $\begin{array}{l}\text { Dead LVS3 + chs3 10\% } \\
+ \text { VC D3 }\end{array}$ & $94 \pm 3^{\circ}$ & $88 \pm 3^{a}$ & $75 \pm 6^{\mathrm{a}}$ & $34 \pm 5^{\mathrm{t}}$ & $0^{\mathrm{b}}$ & $98 \pm 3^{a}$ & $86 \pm 3^{a}$ & $61 \pm 5^{3}$ & $28 \pm 3^{\mathrm{b}}$ & $0^{r}$ \\
\hline 19 & Dead I.VS3(2X) & $98 \pm 3^{a}$ & $93 \pm 3^{a}$ & $84 \pm 3^{3}$ & $78 \pm 3^{\mathrm{a}}$ & $73 \pm 3^{\mathrm{a}}$ & $98 \pm 3$ & $89 \pm 3^{a}$ & $85 \pm 4^{a}$ & $78 \pm 3^{a}$ & $74 \pm 3^{a}$ \\
\hline
\end{tabular}

The yeast cells constituted either $574 \pm 0.2 \mu \mathrm{g} / \mathrm{FT}$ or $287 \pm 0.2 \mu \mathrm{g} / \mathrm{FT}$ of the total AFDW supplied. The challenged test was performed with l'ibrio camphellit (VC) added at day 3. Each experiment was repeated twice: A and B. Each feed was tester in four replicates. The total amount of feed offered is equal to $2870 \mu \mathrm{g}$ AFDW/FT. Means were put together with the standard deviation (mean \pm SD). Survival in the challenge test was compared directly to the survival of non-challenged Artemia. Values showing the same superscript lelter are not significantly different $(p>0.05)$.

shape [30]. As a consequence, a lack of $\beta$-glucans in the yeast cell wall might result in less covalent linkage hetween the three cell-wall compounds, resulting in a more permeable and digestible cell wall in comparison to the WT strain. Although in a WT-yeast strain chitin concentration makes up only 1-2\% of the cell-wall dry mass [22], it plays a key role in yeast cell growth and division and is attached covalently to $\beta-1,3$ glucans, $\beta-1,6$ glucans and mannoproteins [31]. Therefore, the better results obtained with nauplii fed chitin-defective yeast could also be due to an enhanced digestibility of chs3 cells by Artemia, caused by reduced linkage between the three cel1-wall components.

In the gas1 yeast mutant, the production of the glycosylphosphatidylinositol (GPI) anchored protein is inhibited resulting in a non-proper fiber assembly of the cell wall (defective architecture) as well as in reduced $\beta$-glucans $[32,33]$. This apparently results in an eventual digestibility of gas 1 cells by Artemia. Compared to WT-fed nauplii, yeast strains with reduced phosphomannan levels in the cell wall (mnn6) always gave higher Artemia performance mainly due to a higher nauplii survival. This fact could be due to interference of phosphomannans in phosphodiester cross-linking of mannoproteins to $\beta$-glucans [34]. In the experiments shown in Tables 3 and 4, equal amounts of yeast cell particles (feeding schedule of Exps. 1 and 2) are offered. This results in different amounts of AFDW being supplied (Table 2). We therefore, in a further experiment, supplied exactly equal amount of AFDW (see Table 5 - feeding regime for Exp. 3) of the different yeast cells to Artemia (Table 6). Consequently, in these experiments, the feed 
Table \&

Experiment 5: mean daily survival (F) of Artemia fed daily with dead LVS3 and yeast cell strains harvested in the stationary growth phase

\begin{tabular}{|c|c|c|c|c|c|c|c|c|c|c|c|}
\hline \multirow[t]{2}{*}{ TN } & & \multicolumn{5}{|c|}{$\mathrm{A}-\operatorname{survival}(\%)$} & \multicolumn{5}{|c|}{ B - survival $(\%)$} \\
\hline & & Day 2 & Day 3 & Diay 4 & Day 5 & Day 6 & Day 2 & Day 3 & Day 4 & Day 5 & Day 6 \\
\hline 1 & Dead LVS3 + WT $10 \%$ & $93 \pm 3^{a}$ & $88 \pm 3^{a}$ & $79 \pm 5^{\mathrm{a}}$ & $75 \pm 3^{a}$ & $65 \pm 4^{a}$ & $91 \pm 3^{a}$ & $88 \pm 3^{a}$ & $76 \pm 3^{\mathrm{a}}$ & $73 \pm 3^{\mathrm{a}}$ & $6 \pm 5^{a}$ \\
\hline 2 & $\begin{array}{l}\text { Dead LVS3 + WT 10\% } \\
+ \text { VC D3 }\end{array}$ & $3 \pm 3^{\mathrm{a}}$ & $89 \pm 3^{a}$ & $46 \pm 5^{b}$ & $0^{h}$ & $0^{\mathrm{h}}$ & $94 \pm 3^{a}$ & $89 \pm 3^{a}$ & $45 \pm 6^{h}$ & $0^{\mathrm{h}}$ & $0^{\mathrm{h}}$ \\
\hline 3 & Dead LVS3 $+\operatorname{mnn} 910$ \% & $\pm 3^{a}$ & $96 \pm 3^{a}$ & $91 \pm 3^{a}$ & $86 \pm 3^{a}$ & $83 \pm 3^{a}$ & $98 \pm 3^{a}$ & $94 \pm 3^{\mathrm{a}}$ & $89 \pm 5^{\mathrm{a}}$ & $86 \pm 3^{a}$ & $80 \pm 4^{a}$ \\
\hline 4 & $\begin{array}{l}\text { Dead LVS3 + mnn9 } 10 \% \\
+ \text { VC D3 }\end{array}$ & $\pm 3^{a}$ & $95 \pm 3^{a}$ & $86 \pm 3^{a}$ & & & $98 \pm 3^{3}$ & $93 \pm 3^{a}$ & $86 \pm 3^{a}$ & & $69 \pm 3^{a}$ \\
\hline 5 & Dead LVS3 + mnn9 5\% & $4 \pm 3^{\mathrm{a}}$ & $89 \pm 3^{a}$ & $81 \pm 5^{\mathrm{a}}$ & $75 \pm 4^{a}$ & $73 \pm 3^{\mathrm{a}}$ & $98 \pm 3^{a}$ & $91 \pm 3^{2}$ & $80 \pm 6^{\mathrm{a}}$ & $75 \pm 4^{\mathrm{i}}$ & $71 \pm 3^{\mathrm{a}}$ \\
\hline 6 & $\begin{array}{l}\text { Dead LVS3 + mnn9 5\% } \\
+ \text { VC D3 }\end{array}$ & $\pm 3^{a}$ & $88 \pm 3^{a}$ & $61 \pm 5^{a}$ & $23 \pm 3^{b}$ & $0^{\mathrm{h}}$ & $96 \pm 3^{a}$ & $90 \pm 4^{a}$ & 64 & & $0^{\mathrm{h}}$ \\
\hline 7 & Dead LVS3 + mnn6 10\% & $\pm 3^{a}$ & $91 \pm 3^{a}$ & $84 \pm 3^{a}$ & $78 \pm$ & $70 \pm 4^{a}$ & $99 \pm 3^{n}$ & $93 \pm 3^{a}$ & $83 \pm 3^{a}$ & a & $69 \pm 5^{a}$ \\
\hline 8 & $\begin{array}{l}\text { Dead LVS3 + mnn6 } 10 \% \\
+ \text { VC D3 }\end{array}$ & $\pm 3^{\mathrm{a}}$ & $90 \pm 4^{a}$ & $43 \pm 3^{b}$ & $0^{\mathrm{h}}$ & $0^{\mathrm{b}}$ & $99 \pm 3^{3}$ & $91 \pm 3^{\mathrm{a}}$ & $45 \pm 4^{b}$ & & $0^{\mathrm{h}}$ \\
\hline 9 & Dead LVS3 + fks $110 \%$ & $\pm 3^{a}$ & $91 \pm 3^{\mathrm{a}}$ & $81 \pm 3^{a}$ & $76 \pm 3^{a}$ & $0 \times=$ & $98 \pm 3^{a}$ & $91 \pm 3^{a}$ & $84 \pm 3^{i}$ & $4^{\mathrm{a}}$ & $69 \pm 3^{a}$ \\
\hline 10 & $\begin{array}{l}\text { Dead LVS3 + fks I } 105 \\
+ \text { VC D3 }\end{array}$ & $\pm 3^{2}$ & $90 \pm 4^{a}$ & $41 \pm 5^{a}$ & $0^{\mathrm{h}}$ & $0^{\mathrm{b}}$ & $96 \pm 3^{7}$ & $90 \pm 4^{n}$ & & $0^{\mathrm{h}}$ & $0^{h}$ \\
\hline 11 & Dead LVS $3+$ knr4 $10 \%$ & $\pm 3^{a}$ & $89 \pm 3^{a}$ & $85 \pm 4^{a}$ & $78 \pm 3^{2}$ & $71 \pm 5^{a}$ & $96 \pm 3^{7}$ & $91 \pm 3^{a}$ & $84 \pm 3^{a}$ & $76 \pm 5^{\mathrm{a}}$ & $74 \pm 3$ \\
\hline 12 & $\begin{array}{l}\text { Dead LVS3 + knr4 10\% } \\
+ \text { VC D3 }\end{array}$ & $\pm 3^{\mathrm{a}}$ & $88 \pm 3^{3}$ & $46 \pm 5^{b}$ & $0^{\mathrm{h}}$ & $0^{h}$ & $98 \pm 3^{a}$ & $93 \pm 3^{a}$ & $50 \pm$ & $0^{h}$ & $0^{\mathrm{h}}$ \\
\hline 13 & Dead LVS3 + kre6 $10 \%$ & $3^{a}$ & $84 \pm 3^{a}$ & $79 \pm 3^{a}$ & $78 \pm 3^{a}$ & $69 \pm 5^{a}$ & 96 & $88=$ & $a$ & $a$ & $71 \pm$ \\
\hline 14 & $\begin{array}{l}\text { Dead LVS3 + kre6 10\% } \\
+ \text { VC D3 }\end{array}$ & & $86 \pm 3^{a}$ & $41 \pm 5^{b}$ & $0^{\mathrm{l}}$ & $0^{h}$ & $98 \pm 3^{a}$ & $86 \pm 3^{a}$ & $38 \pm 3^{b}$ & $0^{\mathrm{h}}$ & $0^{h}$ \\
\hline 15 & Dead LVS3 + gas $110 \%$ & $1 \pm 3^{a}$ & & $84 \pm 3$ & $73 \pm 3^{0}$ & $69 \pm 3^{9}$ & $93 \pm 3^{a}$ & $89 \pm 3^{2}$ & $83 \pm 3^{a}$ & & $71 \pm 3$ \\
\hline 16 & $\begin{array}{l}\text { Dead LVS3 + gas } 110 \% \\
+ \text { VC D3 }\end{array}$ & $90 \pm 3^{a}$ & $89 \pm 3^{a}$ & $43 \pm 3^{b}$ & $25 \pm 4^{b}$ & $0^{\mathrm{b}}$ & $93 \pm 3^{3}$ & $86 \pm 3^{a}$ & $46 \pm 3^{b}$ & $28 \pm 3^{b}$ & $0^{\mathrm{b}}$ \\
\hline 17 & Dead LVS $3+\operatorname{chs} 310 \%$ & $98 \pm 3^{a}$ & $88 \pm 3^{\mathrm{a}}$ & $83 \pm 3^{a}$ & $75 \pm 4^{a}$ & $68 \pm 3^{a}$ & $96 \pm 3^{a}$ & $89 \pm 5^{a}$ & $84 \pm 3^{a}$ & $78 \pm 3^{\mathrm{a}}$ & $70 \pm 4^{a}$ \\
\hline 18 & $\begin{array}{l}\text { Dead LVS3 }+\operatorname{chs} 310 \% \\
+ \text { VC D3 }\end{array}$ & $98 \pm 3^{a}$ & $89 \pm 3^{a}$ & $68 \pm 3^{b}$ & $0^{\mathrm{b}}$ & $0^{\mathrm{h}}$ & $98 \pm 3^{3}$ & $88 \pm 3^{a}$ & $66 \pm 5^{b}$ & $0^{b}$ & $0^{\mathrm{b}}$ \\
\hline
\end{tabular}

The yeast cells constituted either $5 \%$ or I0\% of the total AFDW supplied. The challenged test was performed with Vibrio campbellii (VC) added at day 3. Fach experiment was repeated twice: A and B. Each feed was tested in four replicates. Means were put together with the standard deviation (mean $t$ SD). Survival in the challenge test $u$ as compared directly to the survival of non-cballenged Artenia. Values showing the same superscript letter are not significantly different $(p=0.05)$

particle concenfration, just after the feeding, was different with the various mutants. Also in this case mnn9-fed Artemia outperformed WT-fed Artemia (both in survival and individual growth). With the other mutants, Artemia biomass production improved mainly through higher survival. With two mutants, namely fks 1 and chs3, Artemia biomass production was equal as in the experiment where WT-cells were offered.

In the present study the Artemia nauplii displayed a higher performance when fed with an exp-grown cells compared with Artemia nauplii fed with stat-grown yeast strains. According to Klis et al. [35], yeast cells entering the stationary phase of growth will form different cell walls, i.e. thicker, more resistant to enzymatic breakdown and less permeable to macromolecules. The level of mannosyl phosphorylation of cell-wall proteins increases in the lateexponential and stationary phase of growth [36]. In addition more extensive cross-Iinking (through disulfide bridges) between the polysaccharide components of the cell wall (mannoproteins, glucans and chitin) is taking place in the stationary phase $[31,37,38]$. In conclusion, it seems that the density of covalent linkage between the three cell-wall compounds of the yeast cell plays an important role in their digestibility by Artemia. In addition to that, high amounts of cell-wall chilin and glucans in combination with low amounts of mannoproteins favour Artemia biomass production under gnotobiotic condition [20,21].

According to Raa [2] improvements in the health status of aquatic organisms can be achieved by balancing the diet with regards to nutritional factors. This phenomenon is identified as nutritional immunology, since some nutritional factors are so closely linked with biochemical processes of the immune system that significant health benefits can be obtained by adjusting the concentration of such factors. Inadequate food or imbalances in the nutrient composition of the diet will affect growth and general performance of an animal, most likely, also the biochemical process of the immune system [2]. In this study nauplii fed with dead LVS3 (5.74 mg AFDW/FT) (Table 5 - feeding 
regime: (d), presented significantly higher survival after challenge in comparison to nauplii fed solely with half of this amount (Table 7). This experiment clearly illustrated that the outcome of the challenge with $V$. campbellii under gnotobiotic condition is very much dependent on the overall condition of the nauplii. These results are also consistent with the perception that Vibrio spp. are opportunistic pathogens. Therefore in all challenge experiments, in which the effect of yeast mutants were tested in small quantities, the total AFDW supplied was kept constant. The mnn 9 -fed Artemia could resist detrimental effect of pathogenic VC until the end of the experiments as previously reported by Marques et al. [25] (Tables 7 and 8). Nevertheless, the addition of $5 \%$ of mnn9 yeast was not able to protect nauplii against VC until day 6 . The mnn9 yeast has a null mutation resulting in phenotypically increased amounts of cell-wall bound chitin and glucans in combination with reduced amount of mannose linked to mannoproteins, and probably a reduced density of covalent linkages between these three yeast cell-wall constituents and/or nature of the covalent bonds, in comparison to the WT strain $[22,29]$. The protection provided by the mnn9 yeast could be the effect of general improvements in Artemia health condition due to extra (or better quality) nutrients available in this yeast or due to a stimulation of a non-specific immune response hy some compounds, such as $\beta$-glucans or chitin that are present in the yeast cell wall. Vismara et al. [39] considerably increased Artemia resistance to stress conditions, such as poor growth medium quality and daily handling, by administering daily nauplii with a mutant of Euglena gracilis presenting high amount of $\beta$-glucans (and thus enabling its response against disease). In contrast to mnn 9 yeast, which has both strong nutritional and/or immunologic characteristics, gas1 cells have good nutritional effects, and protect nauplii temporarily against the pathogen in the challenge test. Furthermore, weak or no nutritional and protection effects were observed with fks1, knr4, mnn6 and kre6 yeast cells (Tables 9 and 10). Yet, interestingly, temporary protection against VC was obtained by adding chs3 in the diet, while this mutant has hardly any effect on individual growth (Table 7). Using the described set of yeast mutants, a full or partial protection against VC can be associated with increased glucan and chitin in the cell wall (e.g. mnn9 but also gas1) and reduced chitin and increased glucan in the cell wall (chs3). This seems to suggest that chitin as such is not involved in the protection against VC. Rather the results indicate that glucan as such is the potential active compound.

$\beta$-glucans have been identified as specific immunostimulants activating the aquatic organisms immune system and protecting them from adverse conditions [7]. For example, yeast Saccharonyces cerevisiae has been found to be

Table 9

Summary tabie of results obtained in the challenged and non-challenged experiments

\begin{tabular}{|c|c|c|c|c|c|c|c|}
\hline \multirow{2}{*}{$\begin{array}{l}\text { Yeast } \\
\text { strains }\end{array}$} & \multirow[t]{2}{*}{ Phenotype } & \multicolumn{3}{|c|}{ Non-challenged experiments (Exps. I-3) } & \multicolumn{3}{|c|}{ Challenged experiments (Exps. 4 and 5) } \\
\hline & & $\begin{array}{l}\text { Survival } \\
\text { (D6) (\%) }\end{array}$ & $\begin{array}{l}\mathrm{II} . \\
(\mathrm{mm})\end{array}$ & $\begin{array}{l}\text { TBP } \\
(\mathrm{mm} / \mathrm{FT})\end{array}$ & $\begin{array}{l}\text { Survival } \\
\text { (D4) (\%) }\end{array}$ & $\begin{array}{l}\text { Survival } \\
\text { (D5) }\left(C_{0}^{\prime}\right)\end{array}$ & $\begin{array}{l}\text { Survival } \\
\text { (D6) }(5)\end{array}$ \\
\hline WT & Control yeast & $\mathrm{C}$ & $\mathrm{C}$ & C. & + & - & - \\
\hline $\min 9$ & $\begin{array}{l}\text { Less mannan, } \\
\text { higher chilin. } \\
\text { higher } \beta \text {-glucáns }\end{array}$ & A & A & A & + & + & + \\
\hline mnn6 & Less phosphomannan & $\mathrm{B}$ & $\mathrm{C}$ & $\mathrm{C}$ & + & - & \\
\hline fks 1 & $\begin{array}{l}\text { Less } \beta-1,3 \text { glucans, } \\
\text { higher chitin }\end{array}$ & B & $\mathrm{C}$ & C. & + & - & - \\
\hline $\mathrm{knr} 4$ & $\begin{array}{l}\text { Less } \beta-1,3 \text { glucans, } \\
\text { highet chitin }\end{array}$ & B & $\mathrm{C}$ & $\mathrm{C}$ & + & - & - \\
\hline kre6 & $\begin{array}{l}\text { Less } \beta-1,6 \text { glucans, } \\
\text { higher chitin }\end{array}$ & B & $\mathrm{C}$ & $\mathrm{C}$ & + & - & - \\
\hline $\operatorname{chs} 3$ & Less chîtin & $\mathrm{B}$ & $C$ & $\mathrm{C}$ & + & $\oplus$ & - \\
\hline gas I & $\begin{array}{l}\text { Less integration of yeast } \\
\text { cell adhesion. proteins } \\
\text { into the cell wall, less } \\
\beta-1,3 \text { glucans, higher chitin }\end{array}$ & B & B & B & + & (1) & - \\
\hline
\end{tabular}

A and B mean respectively statistically different $(p<0.05)$ strong and moderate positive effect of yeast feed on Artemia performance in comparison to the wild type yeast strain. C means no stakistical different effect of feed on Artemia performance in comparison to the wild type yeast strain. " +" means protection (no significant difference in survival rate hetween challenged and non-challenged trearments) provided by small amounts of yeast feed ( 5 or 10\%) on Artemia performance when fed with dead LVS3 and challenged with Vibrio campbellii . "-" means no protection (significant difference in survival rate between challenged and non-challenged treatments). $\oplus$ means that the feed was only protecting partially against the pathogen. D4, D5 and D6 correspond, respectively, to day 4, 5 and 6. 
Table 10

Experimental design of the 5 experiments (Exp.) performed

\begin{tabular}{|c|c|c|c|c|c|c|c|c|c|c|c|}
\hline & & $\begin{array}{l}\text { Day } 1 \\
\text { (start) }\end{array}$ & & Day 2 & & Day 3 & & Day 4 & & Day 5 & $\begin{array}{l}\text { Day } 6 \\
\text { (harvest) }\end{array}$ \\
\hline Exps. $1-3$ & (a) & $\mathrm{Y}$ & $\rightarrow$ & $\mathrm{Y}$ & $\rightarrow$ & $\mathrm{Y}$ & $\rightarrow$ & $\mathrm{Y}$ & $\rightarrow$ & $Y$ & $\rightarrow$ \\
\hline \multirow[t]{6}{*}{ Exps. 4 and 5} & (b) & $\mathrm{DB}+\mathrm{Y}$ & $\rightarrow$ & $\mathrm{DB}+\mathrm{Y}$ & $\rightarrow$ & $\mathrm{DB}+\mathrm{Y}$ & $\rightarrow$ & $\mathrm{DB}+\mathrm{Y}$ & $\rightarrow$ & $\mathrm{DB}+\mathrm{Y}$ & $\rightarrow$ \\
\hline & (c) & $\mathrm{DB}+\mathrm{Y}$ & $\rightarrow$ & $\mathrm{DB}+\mathrm{Y}$ & $\rightarrow$ & $\mathrm{DB}+\mathrm{Y}+\mathrm{P}$ & $\rightarrow$ & $\mathrm{DB}+\mathrm{Y}$ & $\rightarrow$ & $\mathrm{DB}+\mathrm{Y}$ & $\rightarrow$ \\
\hline & (d) & $\mathrm{DB}(\mathrm{X})$ & $\rightarrow$ & $\mathrm{DB}(\mathrm{X})$ & $\rightarrow$ & $\mathrm{DB}(\mathrm{X})$ & $\rightarrow$ & $\mathrm{DB}(\mathrm{X})$ & $\rightarrow$ & $\mathrm{DB}(\mathrm{X})$ & $\rightarrow$ \\
\hline & (e) & $\mathrm{DB}(\mathrm{X})$ & $\rightarrow$ & $\mathrm{DB}(\mathrm{X})$ & $\rightarrow$ & $\mathrm{DA}(\mathrm{X})+\mathrm{P}$ & $\rightarrow$ & $\mathrm{DB}(\mathrm{X})$ & $\rightarrow$ & DB $(X)$ & $\rightarrow$ \\
\hline & (f) & $\mathrm{DB}(2 \mathrm{X})$ & $\rightarrow$ & DB $(2 X)$ & $\rightarrow$ & $\mathrm{DB}(2 \mathrm{X})$ & $\rightarrow$ & $\mathrm{DB}(2 \mathrm{X})$ & $\rightarrow$ & $\mathrm{DB}(2 \mathrm{X})$ & $\rightarrow$ \\
\hline & (g) & $\mathrm{DB}(2 \mathrm{X})$ & $\rightarrow$ & $\mathrm{DB}(2 \mathrm{X})$ & $\rightarrow$ & $\mathrm{DB}(2 \mathrm{X})+\mathrm{P}$ & $\rightarrow$ & $\mathrm{DB}(2 \mathrm{X})$ & $\rightarrow$ & $D B(2 X)$ & $-\rightarrow$ \\
\hline
\end{tabular}

(a-g) correspond to the treatments perfonmed; $Y=$ yeast strains (wild type or isogenic yeast mutants). Yeast strains were added either at an egual amount of yeast cell particles (Exps. I and 2) or an equal amount of feed (Exp. 3), or 5 or 10 so (Exps. 4 and 5); DB $=$ dead bacterium LVS3; X $=$ the

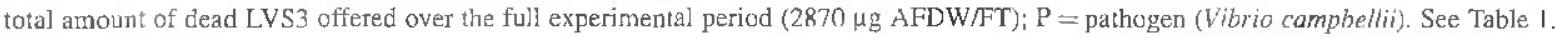

a good enhancer of the trout immune system [40]. Patra and Mohamed [41] showed that Artemia supplemented with Saccharomyces boulardi were protected against Vibrioi harveyi. Immunostimulant properties of wild type yeast (WT) and fks1 mutant strain (resulting in fivefold higher cell-wall bound chitin) were administrated to the diet to gilthead sea bream (Sparus aurata L.) for six weeks under non-axenic conditions [42]. The results showed that chitin-enrichment in the fks 1 strain may be responsible for increasing the innate immune responses resulting in beneficial effects on fish performance. The latter findings are not supported by our results.

In conclusion, the mnn9 yeast strain, even in small quantities, can protect Artemia nauplii against pathogenic bacteria, suggesting that this yeast strain is stimulating the innate immune response. It seems probable that mnn9 cells protect nauplii either through their higher concentration of $\beta$-glucans in the cell wall and/or the higher availability of $\beta$-glucans to nauplii. However, an overall nutritional stimulation by $\mathrm{mnn} 9$ with positive effect on the immunolngical status cannot be excluded. Using chs3 strain (in comparison to WT) as feed has very little extra effect on the growth and survival. Yet, this feed can temporarily protect Artemia against VC.

\section{Acknowledgments}

The Ministry of Science, Research and Technology of Iran for supporting this study through a doctoral grant to the first author. The Belgian Foundation for Scientific Research (FWO) for financing the project "Functional role and characteristics of micro-organisms in the larviculture of aquatic organisms: Artemia as preferred test organism" (no. 350230.02) and the project "Nutritional and immunostimulatory characteristics of isogenic yeast mutants in Artemia" (no. 1.5.125.04).

\section{References}

[1] Bricknell I, Damo RA. The use of immunostimulants in fish larval aquaculture. Fish Shellfish Immunol 2005;19:457-72.

[2] Raa J. The use of immune-stimulants in fish and shellfish feeds. In: Cruz-Suárez L, et al., editors. Avances en Nutrición Acuícola V. Memorias del V Simposium Intemecional de Nutrición Acuícola November 19-22, 2000. Mérida. Yucatán, Mexico: 2000.

[3] Kurtz J, Franz K. Innate defence: evidence for memory in invertebrate immunity. Nature 2003:425:37-8.

[4] Alabi A, Jones D, Latchford J. The efficacy of immersion as opposed to oral vaccination of Penaeus indicus larvae against Vibrio harveyi. Aquaculsure 1999;178:1-11.

[5] Itami T, Asano M, Tokushige K, Kubono K, Nakagawa A, Takeno N, et al. Enhancement of disease resistance of kuruma shrimp, Penaeus japonicus. after oral administration of peptidoglycan derived from Bifidobacterium thermophilium. Aguaculbure 1998:164:277-88.

[6] Teunissen OSP. Faber R, Booms GHR, Latscha T. Ronn JH. Influence of vaccination on vibriosis resistance of the giant black tiger shrimp Penaeus monodon (Fabricius) Aquaculture 1998; I64:359-66.

[7] Anderson DP. Immunostimulants, adjuvants and vaccine carriers in fish: applications to aquacultule. Annu Rev Fish Dis 1992;2: $281-307$.

[8] Sung H, Yang Y, Song Y. Enhancement of mícrobicidal activity in the riger shrimp, Penneus monodon, via immunostimulation. J Crust Biol 1996; 16:278-84

[9] Sritunyalucksana K. Sithisarn P, Withayachumnarnkul B, Flegel T. Activation of prophenoloxidase, agglutinin and antibacterial activity in haemolymph of the black tiger prawn, Penaeus monodon, by immunostimulants. Fish Shellfish Immunol 1999:9:21-30. 
[10] Burgents J, Burneft K, Burnett L. Disease resistance of Pacific white shrimp, Litopenaeus vannamei, following the dietary administration of a yeast culture food supplement. Aquaculture 2004;231:1-8.

[111 Misra C, Das B, Pradhan J, Pattnaik P, Sethi S, Mukherjee S. Changes in lysosomal enzyme activity and protection against Vibrio infection in Macrobrachium rosenbergii (De Man) post larvae after bath immunostimulation with $\beta$-glucan. short communication. Fish Shellfish Immunol 2004;17:389-95.

[12] Anderson D. Siwicki A. Duration of protection against Aeromonas salmonicida in brook trout immunostimulated with glucan or chitosan by injection or immersion. Prog Fish Culturist 1994;56:258-61.

[13] Song YL, Huang CC. Application of immunostimulants to prevent shrimp diseases. In: Fingerman M, Nagabhushanam R, editors. Recent advances in marine biotechnology. Immtunobiology and pathology, vol. 5. Enfield, NH, USA: Science Publishers; 1999. p. 173-88.

[14] Wang SH, Chen JC. The protective effect of chitin and chitosan against Vibrio alginolyticus in white shrimp Litopenaeus rannamei. Fish Shellfish Immunol 2005;3:191-204.

[15] Tizard I, Carpenter R, McAnalley B, Kemp M. The biological activities of mannans and related complex carhohydrates. Mol Biother $1989 ; 1: 290-6$.

[16] Takahashi Y, Kondn M, Itami T, Honda T. Inagawa H. Nishizawa T, et al. Enhancement of disease resistance against penaeid acute viraemia and induction of virus-inactivating in haemolymph of kuruma shrimp, Penaeus japonicus, by administraticn of Pantoea agglomerans lipopolysaccharide (LPS). Fish Shellfish Immunol 2000;10:555-8.

[17] Boonyaratpalin S, Bnonyaratpalin M, Supamattaya K, Toride Y. Effects of peptidoglycan (PG) on growlh, survival, immune response, and tolerance to stress in black tiger shrimp, Penaeus monodon. In: Shariff M, et al., editors. Diseases in Asian aquaculture II. Fish health section. Manila, Philippines: Asian Fisheries Society; 1995.

[18] Keith I, Paterson W, Aidrie D, Boston L. Defense mechanisms of the American lobster (Homarus americanus): vaccination provided protection against Gaffremia infections in laboratory and field trials. Fish Shellfish Immunol 1992;2:109-19.

[19] Vicj V, Singh B, Bhat S. Application of bacterins and yeast Acremonium dyosporit to prolect the larvae of Macrobrachium rosenbergii from vibijosis. Fish Shellfish Immunol 2000;10:559-63.

[20] Marques A, François J, Dhont J, Bossier P, Sorgeloos P. Influence of yeast quality on performance of gnotobiotically-grown Artemia, J Exp Mar Biol Ecol 2004;310:247-64.

[21] Marques A, Dhont J, Sorgeloos P, Bossier P. Evaluation of different yeast cell wall mutants and microalgae strains as feed for gnotobiotically-grown brine shrimp Artemia franciscana. J Exp Mar Biol Ecol 2004;312:115-36.

[22] Magnelli P, Cipolin J, Abeijon C. A refined method for the determination of Saccharomyces cerevisiae cell wall composition and $\beta-1$, 6-glucan fine strucrure. Anal Biochem 2002;301:136-50.

[23] Verschuere L. Rombaut G. Huys G, Dhon1 J. Sorgeloos P, Verstraete W. Microbial control of the culture of Artemia juveniles through preemptive colnnization by selected bacterial strains. Appi Envinn Microbiol 1999:65:2527-33.

[24] Verschuere L, Heang H, Criel G, Sorgelons P, Verstraete W. Selected baclerial strains protect Artenia spp. from pathogenic effects of Vibrio proteolyicus CW8T?. Appl Environ Microhiol 2000;66:1139-46.

[25] Marques A, Dinh T, Ioakeimidis C, Huys G, Swings J, Verstraete W, et al. Effects of bacteria on Artemia franciscana cultured in different gnotobiotic environments. Appl Environ Microbiol 2005;71:4307-17.

(26] Soto-Rodriguez S, Rnque A, Lizarraga Partida M, Guelra-Flores A, Gomez-Gil B. Virulence of luminous vibrios io Artemia franciscana nauplii. Dis Aquat Organ 2003:53:231--40.

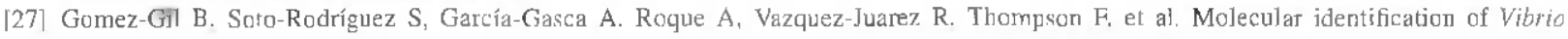
harveyi-related isolates associated with diseased aquatic organisms. Microbiology 2004;150;1769-77

[28] Coutteau P, Lavens P, Sorgeloos P. Baker's yeast as a potential subscitute for live algae in aquaculture diets: Artemia as a case study. J World Aquacult Soc 1990;21:1-8.

[29] Aguilar-Uscanga B, Francois J. A study of the yeast cell wall composition and structure in response to growth conditions and mode of cultivation. Let Appl Microbiol 2003;37:268-74.

[30] Martine-Yken H, T.agorce A, Dagkessamanskia A, Francois J. Yeast cell wall structure and assembly in re]ation with the cell growth and morphogenesis, Recent Res Dex Biochem 2002;6:503-27.

[31] Cabib E, Ruh D, Schmidt M. Crotti L, Varma A. The yeast cell wall and septum as paradigm of cell grcwth and morphogenesis-mini review J Biol Chem 2001:276:19679-82.

[32] Ram AFJ, Kapteyn JC, Montijn RC, Caro LHP, Douwes JE, Baginsky W, et al. Loss of plasma membrane-bound protein Gas IP in Saccharomyces cerevisiae results in the release of $\beta 1,3$-glucan into the medium and induces a compensation mechanism to ensure cell wall integrity. I Bacteriol 1998:180:1418-24.

[33] Lipke PN, Ovalle. R. Cell wall architecture in yeast: new stlucture and new challenges. J Racterjol 1998;180:3735-40.

[34] Jigami Y, Odani T. Mannosylphosphate transfer to yeast mannane. review. Biochim Biophys Acta 1999;1426:335-45.

「35] Klis K, Mol P, Hellingwerf K, Brul S. Dynamics of cell wall struciure in Saccharonyces cerevisiae. FEMS Microhinl Rev 2002;26:239-56.

[36] Odani T, Shimma Y, Wang X. Jgami Y. Mannosylphosphate transfer to cell wall mannan is regulated by the 1ranscriptional level of the MNN4 gene in Saccharomyces cerevisiae. FFBS Lett 1997;420:186-90.

[37] Deutch C, Parry J. Sphaeroplast formation in yeast during the transition from exponential to stationary phase. J Gen Microbiol 1974;80: $259-68$.

[38] De Nobel H, Ruiz, C, Martin H, Morris W. Brul S, Molina M, et al. Cell wall pertubation in yeast results in dual phosphorylation of the Slt2/ Mpk1 MAP kinase and in an S1t2-mediated increase in FKS2-lacZ expression, glucanase resistance and thermotolerance. Microbiology 2000; 146:212 I-32

[39] Vismara R, Vestri S, Frassanito A, Barsanti L. Gualtieri P. Stress resistance induced by paramylon treatment in Artemis sp. I Appl Phyco] 2004:16:61-7. 
[40] Siwicki AK, Anderson DP, Rumsey GL. Dietary intake of immunostimulants by raineow trout affects non-spectific immunity and protection against furunculosis. Vet Immunol and Immunopathol 1994;41:125-39.

[4 I] Patra S, Mohamed K. Enrichment of Artemia nauplii with the probiotic yeast Saccharonyces boulardii and its resistance against a pathogenic Vibrio. Aquacult Int 2003:11:505-14.

[42] Rodriguez A, Cuesta A, Or1uño J, Esteban MA, Meseguer J. Immunostimulant properties of a cell wall-modified whole Saccharomyces cerevisiae strain administered by diet to sea bream (Sparus aurata L.). Vet Immunol and Immunopathol 2003:96:183-92.

[43] Dallies N, François J, Paquet V. A new method for quantitative determination of pclysaccharides in the yeast cell wall. Application 10 the cell wall defective mutants of Saccharomyces cerevisine. Yeast 1998;14:1297-306.

[44] Karson FM, Ballou CE. Binsynthesis of yeast mannan. Properties of a mannosylphosphate transferase in Sacrharomyces cerevisiae. J Bio] Chem 1978;253(18):6484-92.

[45] Wang XH, Nakayama KI. MNN6, a member of the KRE2/MNT1 family, is the gene for mannosylphosphate iransfer in Saccharomyces cerevisiae. J Binl Chem 1997;272(29):18117-24.

[46? Pagé N. Gérard-Vincent M. Ménard P. Beaulieu M. Azuma M, Dijkgraaf G, et al. A Sacrharonyces cererisiae genome-wide mutant screen for altered sensitivity to K1 killer toxin. Genetics 2003;163:875-94.

[47] Valdivieso M, Ferrario L, Vai M, Duran A, Popolo L. Chitin synthesis in a gas1 mutant of Saccharomyces cererisiae. J Bacterio] 2000;182(17):4752-7.

[48] Popolo L, Gilardelli D, Bonfante P, Vai M. Increase in chitin as an essential response to defects in assembly of cell wall polymers in the ggpl 1 mutant of Saccharomyces cerevisiae. J Bacteriol 1997;179-463-9. 


